\title{
Radiocarbon calibration: The next generation
}

\author{
Richard A STAFF ${ }^{*}$ \& Ruiliang LIU ${ }^{2 \dagger}$ \\ ${ }^{1}$ Scottish Universities Environmental Research Centre (SUERC), University of Glasgow, East Kilbride G75 0QF, UK; \\ ${ }^{2}$ School of Archaeology, University of Oxford, Oxford OX1 3TG, UK
}

Received September 8, 2020; revised November 28, 2020; accepted January 21, 2021; published online February 1, 2021

Citation: Staff R A, Liu R. 2021. Radiocarbon calibration: The next generation. Science China Earth Sciences, 64(3): 507-510, https://doi.org/10.1007/s11430020-9722-x

The discovery of the radiocarbon $\left({ }^{14} \mathrm{C}\right)$ dating technique in the mid-twentieth century by Willard Libby and colleagues (Libby et al., 1949) revolutionised such fields as archaeology and palaeoclimatology that require robust chronological information to inform their study. Any sample yielding sufficient quantities of carbon could be dated in this manner, with the older age limit of the method (currently circa 50 to 60 thousand years ago) having been pushed back significantly since its inception.

However, it soon became apparent that a calibration stage was required in the process to convert "raw" radiocarbon determinations obtained from samples into a meaningful representation of the passing of "real" calendar time (de Vries, 1958). Such calibration is necessary since the concentration of the radioisotope ${ }^{14} \mathrm{C}$ in the ambient atmosphere relative to stable ${ }^{12} \mathrm{C}$ and ${ }^{13} \mathrm{C}$ is not constant through time. This is the result of both variability in the production rate of ${ }^{14} \mathrm{C}$ in Earth's upper atmosphere-in turn the result of fluctuations in both the geomagnetic field intensity, as well as the strength of the solar wind-and rearrangements in the relative distribution of carbon between the respective reservoirs of Earth's carbon cycle system.

Calibration is achieved through the comparison of samples' measured ${ }^{14} \mathrm{C}$ determinations with those of an empirically derived calibration curve that consists of thousands of ${ }^{14} \mathrm{C}$ measurements of "known age" (i.e., independently geochronologically dated) samples. In order to maintain consistency of the method, the international radiocarbon

\footnotetext{
* Corresponding author (email: richard.staff@glasgow.ac.uk)

$\uparrow$ Corresponding author (email: ruiliang.liu@arch.ox.ac.uk)
}

community endorses a set of "definitive" consensus calibration curves that users of the ${ }^{14} \mathrm{C}$ dating method are expected to implement.

Since 2004, compilation of these calibration curves has been overseen by the "IntCal" (International Calibration) Working Group, which release updates at semi-regular intervals as new contributing data become available and knowledge of the Earth system improves. In August 2020, the latest iterations of the consensus calibration curves were published in the journal Radiocarbon, superseding the previous "IntCal13" iterations, namely: (1) "IntCal20", for calibration of ${ }^{14} \mathrm{C}$ samples drawing their carbon from the Northern Hemisphere atmosphere (Reimer et al., 2020); (2) "SHCal20", for samples drawing their carbon from the Southern Hemisphere atmosphere (Hogg et al., 2020); and (3) "Marine20", for samples drawing their carbon from the ocean surface layer (Heaton et al., 2020b).

These new calibration curves have been updated to incorporate a plethora of new data that has been produced by a multitude of scientists, from numerous contributing laboratories over the intervening seven years, with strict data quality criteria needing to be met in order for their inclusion (Reimer et al., 2013a). The statistical methods applied in the generation of the calibration curves from their constituent datasets have also been significantly updated, with a Bayesian spline approach replacing the previous random walk model (Heaton et al., 2020a). All three curves now extend back to 55000 calibrated years Before Present (cal BP), representing a 5000 year extension compared to the previous chronological limit.

For the most recent 12310 calibrated years, the principal 
curve, IntCal20, consists entirely of ${ }^{14} \mathrm{C}$ measurements of robustly, independently dendrochronologically dated treerings, with an extended period back to circa 13910 cal BP composed of "floating" tree-ring sequences (i.e., those lacking an "absolute" dendrochronology). A significant advancement for IntCal20 is the inclusion of a large number of ${ }^{14} \mathrm{C}$ measurements from individual tree-rings, for the first time providing annual chronological resolution for sections of the curve. To a large extent, this development has been driven by the search for so-called "Miyake events"-very rapid (sub-annual) increases in atmospheric ${ }^{14} \mathrm{C}$ concentration - following the initial discovery by Miyake et al. (2012) of one such prominent event that occurred in 774-775 CE (1175-1176 cal BP) and which is attributed to an extreme solar proton event.

Further back in time, the central contributing dataset and key addition to this latest update to the calibration curve is that provided by the Hulu Cave (China) speleothems (Cheng et al., 2018), which are precisely, independently uranium-thorium (U-Th) dated. This dataset is supplemented by data from further floating tree-ring sequences, other speleothems, foraminifera from marine sediment cores, and marine corals. In addition, perhaps the most important supporting data through this older time period remain ${ }^{14} \mathrm{C}$ measurements of plant macrofossil samples picked from the annually laminated (varved) lacustrine sediment cores from Lake Suigetsu, Japan (Bronk Ramsey et al., 2020) which, along with the tree-rings, provide a direct record of atmospheric ${ }^{14} \mathrm{C}$ concentration. This is not the case with the speleothem or marine archives which do not draw their carbon directly from the ambient atmosphere, and consequently require "dead carbon fraction" (DCF) or "marine reservoir" corrections which incorporate additional uncertainties into their ${ }^{14} \mathrm{C}$ determinations.

Users of the radiocarbon dating technique will be most concerned with where differences lie between the new IntCal20 calibration curve (Reimer et al., 2020) and the previous iteration, IntCal13 (Reimer et al., 2013b). As a first order observation, these changes can be summarised as being far more subtle through the Holocene (i.e., the most recent $\sim 11700$ years), for which the calibration curve was already composed of robust, independently dendrochronologically dated tree-rings, whereas more marked modifications are evident further back in time, where the constituent records underlying the calibration curve are less secure.

One brief Late Holocene period of divergence occurs circa 50-250 CE (1900-1700 cal BP; Figure 1), where the previous calibration curve has been supplemented with new measurements upon Japanese tree-rings. This time period roughly coincides with the latter half of the Han Dynasty in China, and is historically significant for the arrival of Buddhism into the country. A radiocarbon sample with a measured radiocarbon "age" of $1900 \pm 25{ }^{14} \mathrm{C}$ years BP would now date approximately 50 calibrated years younger using the revised IntCal20 curve compared with the previous IntCal13 curve (Figure 1).

The remainder of the Holocene section demonstrates very similar structure between the IntCal13 and IntCal20 curves (Figure 2a and 2b). Accordingly, this means that in the field of Chinese archaeology, where the majority of radiocarbon dates are attributed to the Neolithic and Bronze Age, the current chronological framework remains largely unchanged; the findings of major research programmes involving chronological reconstruction, such as investigating the peopling of the Tibetan Plateau (Chen et al., 2015), the human-land relationship along the Silk Road (Dong et al., 2020), or the emergence of complex society in China (Renfrew and Liu, 2018), would not be significantly affected by the update to the calibration curve.

There is more marked deviation between the IntCal13 and IntCal20 curves in the latest pre-Holocene period (circa 14000 to $12000 \mathrm{cal}$ BP), however, with much greater detail shown in the updated dataset (Figure 2c), which is largely a result of the addition of a large amount of single year treering data through this interval.

Back further in time, the updated calibration curve largely

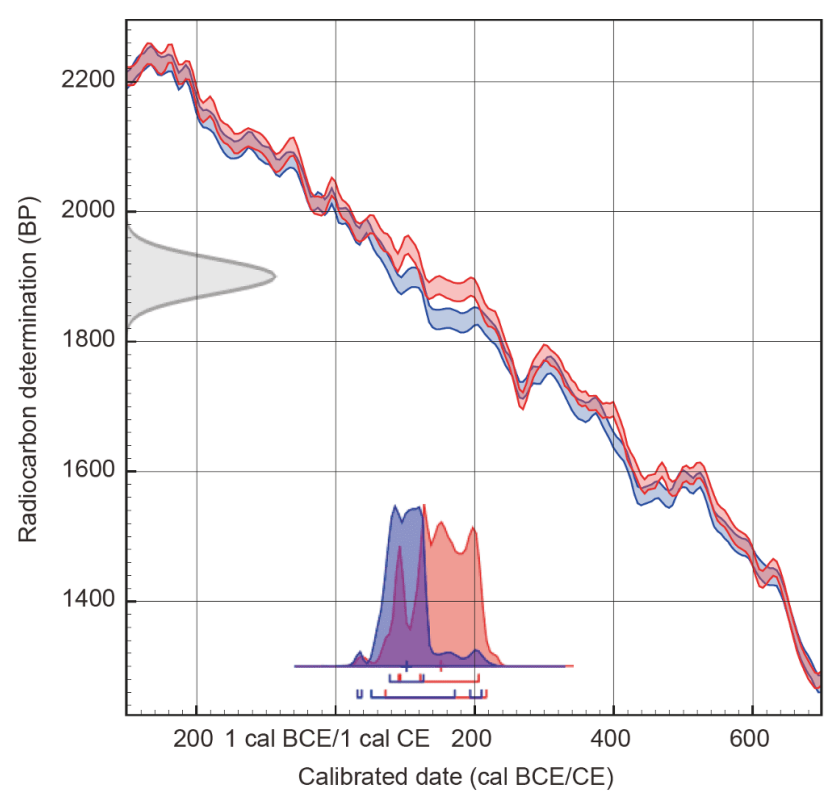

Figure 1 (Color online) A comparison of the previous (IntCal13, blue; Reimer et al., 2013b) and recently updated (IntCal20, red; Reimer et al., 2020) radiocarbon calibration curves for the time period $300 \mathrm{BCE}$ to 700 $\mathrm{CE}$, illustrating the impact of the updated calibration curve on a hypothetical sample dating to $1900 \pm 25{ }^{14} \mathrm{C}$ years Before Present (BP) (grey probability distribution on the $y$ axis). Using IntCal13, highest probability density (HPD) ranges of $78-126$ cal CE (at $68.3 \%$ probability) and 31-37, 51-171 and 193-210 cal CE (95.4\% probability) are produced (blue horizontal bars underneath the blue probability density function, PDF); whereas, using IntCal20, HPD ranges of 89-91 and 120-204 cal CE (at $68.3 \%$ probability) and $70-215$ cal CE (95.4\% probability) are produced (red horizontal bars underneath the red PDF). Median ages (plotted as crosses along the PDFs) are $102 \mathrm{cal} \mathrm{CE}$ and $150 \mathrm{cal} \mathrm{CE}$, respectively, demonstrating a shift to younger ages of approximately 50 calibrated years using the updated calibrated curve. Both calibration curves are plotted with $1 \sigma$ uncertainty envelopes. 

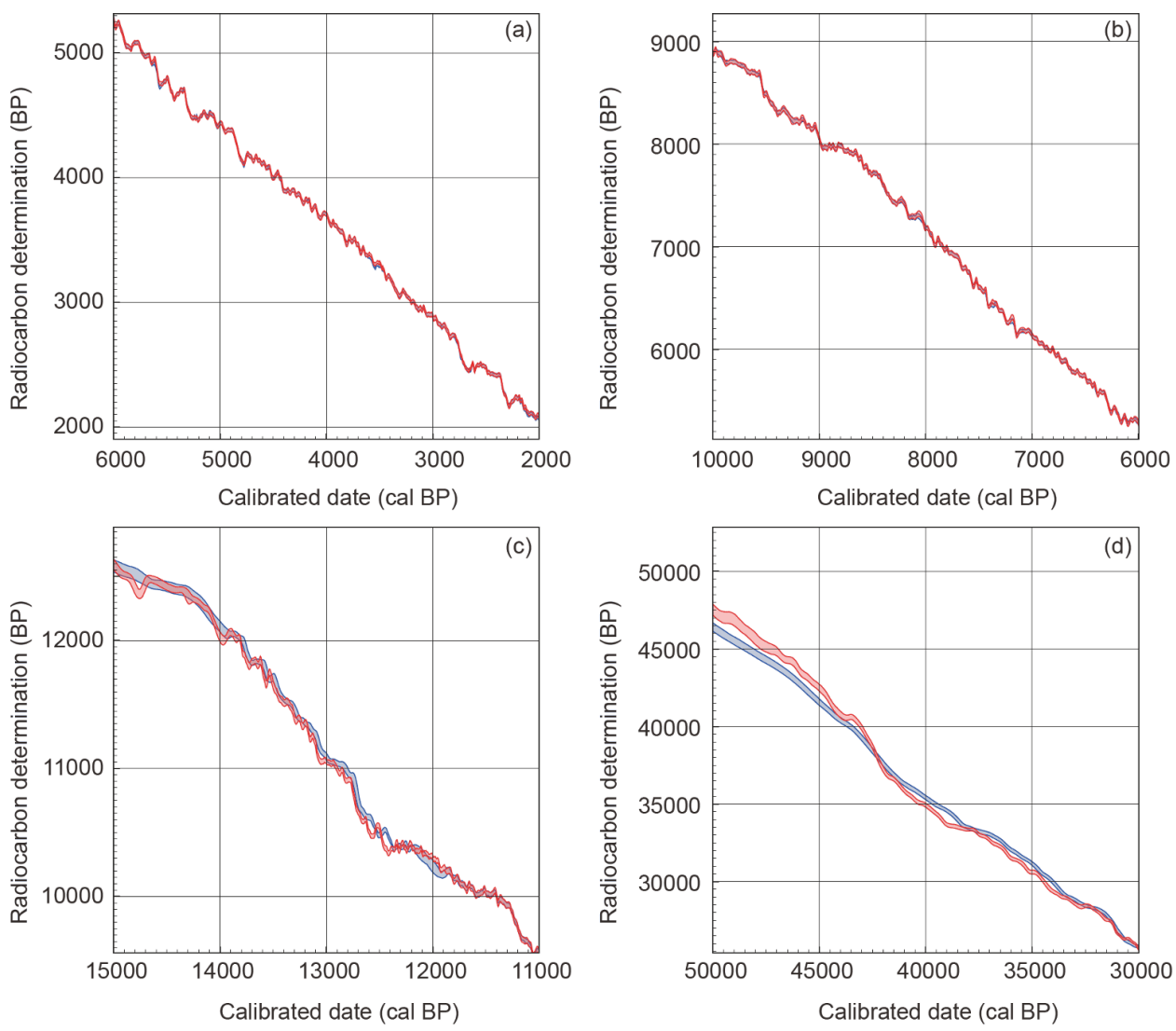

Figure 2 (Color online) A comparison of the previous (IntCal13, blue; Reimer et al., 2013b) and recently updated (IntCal20, red; Reimer et al., 2020) radiocarbon calibration curves for selected time periods referred to in the main text: (a) 6000-2000 cal BP (= 4051-51 cal BCE); (b) 10000-6000 cal BP; (c) 15000-11000 cal BP; and (d) 50000-30000 cal BP. Both calibration curves are plotted with $1 \sigma$ uncertainty envelopes.

tracks the previous iteration, albeit that the IntCal20 curve now includes more detailed structure compared to the overly smooth IntCal13. This is the result of the incorporation of new, high resolution data (principally from the Hulu Cave speleothems), as well as the improved statistical methods for synthesising the multiple contributing datasets (Heaton et al., 2020a). However, before $33000 \mathrm{cal} \mathrm{BP}$, there is greater divergence between the previous and updated calibration curves (Figure 2d); between circa 42000 and 33000 cal BP IntCal20 provides older calibrated ages than IntCal13 (by up to approximately 700 calibrated years circa 39000 cal BP), whereas for the oldest period of time, IntCal20 now provides slightly younger ages (by up to about 1000 calibrated years circa $49000 \mathrm{cal}$ BP). Again, these revisions are largely the result of the incorporation of the Hulu Cave speleothem data, with their robust underlying U-Th timescale.

Atmospheric ${ }^{14} \mathrm{C}$ concentration in the Southern Hemisphere is slightly depleted relative to the Northern Hemisphere, which is related to the greater surface area of ocean in the former and the related air-sea ${ }^{14} \mathrm{CO}_{2}$ flux. Consequently, ${ }^{14} \mathrm{C}$ calibration in the Southern Hemisphere requires a separate curve, SHCal20 (Hogg et al., 2020), which, like its Northern Hemisphere counterpart, has been updated with the implementation of the improved statistical integration ap- proach as well as the addition of new tree-ring data. Nevertheless, a curve composed solely of Southern Hemisphere data is only possible for short time intervals (circa 2140-0 cal BP, 3520-3453 cal BP, 3608-3590 cal BP, and 13140-11375 cal BP), and therefore Northern Hemisphere data from IntCal20 need to be utilised for the remainder of SHCal20, applying a statistical model to account for the variable inter-hemispheric offset in atmospheric ${ }^{14} \mathrm{C}$ concentration. From the period for which contemporaneous data are available from the Northern and Southern Hemispheres, a time-varying offset averaging $36 \pm 27{ }^{14} \mathrm{C}$ years is demonstrated (with the Southern Hemisphere apparently older).

For regions within the intertropical convergence zone (ITCZ), it is recommended to use a mixed curve to account for the influence of both Northern and Southern Hemisphere air masses within these tropical and sub-tropical regions (Hogg et al., 2020).

Finally, Marine20 applies to samples from the conceptual globally-averaged mixed ocean layer (Heaton et al., 2020b), which is depleted in ${ }^{14} \mathrm{C}$ relative to the atmosphere, and which smooths out higher frequency signal, due to the residence time of carbon in the ocean. This depletion is temporally and spatially variable, and therefore region-specific marine radiocarbon reservoir age corrections must be ad- 
ditionally applied. The curve is specifically for samples from non-polar regions (defined approximately as $40^{\circ} \mathrm{S}$ to $40^{\circ} \mathrm{N}$ (Pacific Ocean) or to $50^{\circ} \mathrm{N}$ (Atlantic Ocean), since local sea ice extent and, in particular, its variability through time, may more significantly affect marine reservoir ages at higher latitudes (Heaton et al., 2020b). The Marine20 curve was generated utilising an ocean/atmosphere/biosphere global carbon cycle box model informed by $\mathrm{CO}_{2}$ data from the polar ice cores and ${ }^{14} \mathrm{C}$ data from the Northern Hemisphere atmospheric curve (IntCal20).

These revised curves should result in more accurate calibrated ages generated from the radiocarbon dating method. However, it should be noted that "increased accuracy" does not equate to "increased precision", since the additional, higher frequency structure ("wiggles") within the updated datasets, which more reliably represent the authentic past variability of atmospheric ${ }^{14} \mathrm{C}$ concentrations, will lead to broader-or, indeed, multimodal - probability distributions for calibrated ages from certain intervals (e.g., Figure 1). By extension, the increased accuracy of individual calibrated radiocarbon data will lead to increased accuracy (though, again, not necessarily increased precision) of the outputs of (e.g., Bayesian) statistical models that combine these individual data (the "likelihoods") according to (e.g., stratigraphic) relationships between the samples (the model "prior").

The three updated radiocarbon calibration curves represent the current best state of knowledge of the international radiocarbon dating community, and are the culmination of decades of work. Nevertheless, on-going research over the coming years and decades will no doubt advance our knowledge yet further, leading to future, ever more robust enhancements of the radiocarbon calibration curves, and improving the ability of the wide ranging ${ }^{14} \mathrm{C}$ user community to glean robust chronological information in relation to the multitude of scientific areas of investigations dependent upon the technique.

Acknowledgements All figures in the present manuscript were made using the Bayesian chronological software OxCal ver.4.4 (https://c14.arch. ox.ac.uk/oxcal/OxCal.html), made freely available by Prof. Christopher Bronk Ramsey. On behalf of the global ${ }^{14} \mathrm{C}$ user community, the authors gratefully thank Prof. Paula Reimer, the outgoing co-ordinator of the "IntCal" (International Calibration) Working Group, for her tireless work in the role over the last two decades. Dr. Ruiliang Liu acknowledges financial support from the European Research Council (ERC) Advanced Grant, "FLAME", awarded to Prof. A Mark Pollard (Grant No. 670010) and from the University of Oxford John Fell Fund (Grant No. 0007844).

Open Access This article is distributed under the terms of the Creative Commons Attribution 4.0 International License (http://creativecommons. org/licenses/by/4.0/), which permits unrestricted use, distribution, and reproduction in any medium, provided you give appropriate credit to the original author(s) and the source, provide a link to the Creative Commons license, and indicate if changes were made.

\section{References}

Bronk Ramsey C, Heaton T J, Schlolaut G, Staff R A, Bryant C L, Brauer A, Lamb H F, Marshall M H, Nakagawa T. 2020. Reanalysis of the atmospheric radiocarbon calibration record from Lake Suigetsu, Japan. Radiocarbon, 62: 989-999

Chen F H, Dong G H, Zhang D J, Liu X Y, Jia X, An C B, Ma M M, Xie Y W, Barton L, Ren X Y, Zhao Z J, Wu X H, Jones M K. 2015. Agriculture facilitated permanent human occupation of the Tibetan Plateau after 3600 B.P. Science, 347: 248-250

Cheng H, Edwards R L, Southon J, Matsumoto K, Feinberg J M, Sinha A, Zhou W, Li H, Li X, Xu Y, Chen S, Tan M, Wang Q, Wang Y, Ning Y. 2018. Atmospheric ${ }^{14} \mathrm{C} /{ }^{12} \mathrm{C}$ changes during the last glacial period from Hulu Cave. Science, 362: 1293-1297

de Vries H L. 1958. Variation in concentration of radiocarbon with time and location on Earth. Proc Koninklijke Nederlandse Akademie van Wetenschappen B, 61: 94-102

Dong G, Li R, Lu M, Zhang D, James N. 2020. Evolution of humanenvironmental interactions in China from the Late Paleolithic to the Bronze Age. Prog Phys Geography-Earth Environ, 44: 233-250

Heaton T J, Blaauw M, Blackwell P G, Bronk Ramsey C, Reimer P J, Scott E M. 2020a. The IntCal20 approach to radiocarbon calibration curve construction: A new methodology using Bayesian splines and errors-invariables. Radiocarbon, 62: 821-863

Heaton T J, Köhler P, Butzin M, Bard E, Reimer R W, Austin W E N, Bronk Ramsey C, Grootes P M, Hughen K A, Kromer B, Reimer P J, Adkins J, Burke A, Cook M S, Olsen J, Skinner L C. 2020b. Marine20 - The marine radiocarbon age calibration curve (0-55000 cal BP). Radiocarbon, 62: 779-820

Hogg A G, Heaton T J, Hua Q, Palmer J G, Turney C S, Southon J, Bayliss A, Blackwell P G, Boswijk G, Bronk Ramsey C, Pearson C, Petchey F, Reimer P, Reimer R, Wacker L. 2020. SHCal20 Southern Hemisphere calibration, 0-55000 years cal BP. Radiocarbon, 62: 759-778

Libby W F, Anderson E C, Arnold J R. 1949. Age determination by radiocarbon content: World-wide assay of natural radiocarbon. Science, 109: $227-228$

Miyake F, Nagaya K, Masuda K, Nakamura T. 2012. A signature of cosmic-ray increase in AD774-775 from tree rings in Japan. Nature, 486: 240-242

Reimer P J, Bard E, Bayliss A, Beck J W, Blackwell P G, Bronk Ramsey C, Brown D M, Buck C E, Edwards R L, Friedrich M, Grootes P M, Guilderson T P, Haflidason H, Hajdas I, Hatté C, Heaton T J, Hogg A G, Hughen K A, Kaiser K F, Kromer B, Manning S W, Reimer R W, Richards D A, Scott E M, Southon J R, Turney C S M, van der Plicht J. 2013a. Selection and treatment of data for radiocarbon calibration: An update to the International Calibration (IntCal) criteria. Radiocarbon, 55: 1923-1945

Reimer P J, Bard E, Bayliss A, Beck J W, Blackwell P G, Bronk Ramsey C, Buck C E, Cheng H, Edwards R L, Friedrich M, Grootes P M, Guilderson T P, Haflidason H, Hajdas I, Hatté C, Heaton T J, Hoffmann D L, Hogg A G, Hughen K A, Kaiser K F, Kromer B, Manning S W, Niu M, Reimer R W, Richards D A, Scott E M, Southon J R, Staff R A, Turney C S M, van der Plicht J. 2013b. IntCal13 and Marine13 radiocarbon age calibration curves $0-50000$ years cal BP. Radiocarbon, 55: $1869-1887$

Reimer P J, Austin W E N, Bard E, Bayliss A, Blackwell P G, Bronk Ramsey C, Butzin M, Cheng H, Edwards R L, Friedrich M, Grootes P M, Guilderson T P, Hajdas I, Heaton T J, Hogg A G, Hughen K A, Kromer B, Manning S W, Muscheler R, Palmer J G, Pearson C, van der Plicht J, Reimer R W, Richards D A, Scott E M, Southon J R, Turney C S M, Wacker L, Adolphi F, Büntgen U, Capano M, Fahrni S M, Fogtmann-Schulz A, Friedrich R, Köhler P, Kudsk S, Miyake F, Olsen J, Reinig F, Sakamoto M, Sookdeo A, Talamo S. 2020. The IntCal20 Northern Hemisphere radiocarbon age calibration curve (0-55 cal kBP). Radiocarbon, 62: 725-757

Renfrew C, Liu B. 2018. The emergence of complex society in China: The case of Liangzhu. Antiquity, 92: 975-990 